\title{
Determination of Hematologic Reference Values of Neonates in Mashhad - Iran
}

\author{
Mohammad R. KERAMATI' ${ }^{1}$, Ashraf MOHAMMADZADEH ${ }^{1}$, Ahmad S. FARHAT ${ }^{1}$, Ramin SADEGHI ${ }^{2}$
}

' Mashhad University, Medical Sciences, Neonatal Research Center

${ }^{2}$ Mashhad University, Medical Sciences, Nuclear Medicine Research Center, Mashhad, IRAN

\begin{abstract}
The results of laboratory tests have little practical utility unless clinical studies have ascribed various states of health and disease to intervals of values. Several factors affect hematologic values, including race, environment, time of sampling, test method, blood collection site, gestational age and maternal factors. Since these factors vary in various populations, they can cause differences in reference hematologic values. Between September 2007 and March 2008, 447 healthy neonates with more than $2500 \mathrm{~g}$ weight were selected and cord blood specimen was taken using EDTA as the anticoagulant. Complete blood count, hemoglobin, hematocrit, and RBC indices were measured by Sysmex cell counter. Differential leukocyte counts were determined in peripheral blood smear. Data were analyzed by SPSS software (version 11.50). A p value $<0.05$ was considered to be significant. Mean values and reference ranges of hematologic parameters were as follows: WBC $\left(\times 10^{3} \mu l\right)=11.62(5.16-18.2), \operatorname{RBC}\left(x 10^{6} \mu l\right)=4.45$ (3.61-5.29), Hb $(\mathrm{g} / \mathrm{dll})=15.9(13-18.8), \mathrm{Hct}(\%)=48.3(39.6-56.9), \mathrm{MCV}(\mathrm{f})=$ 108.7 (97.5-119.8), $\mathrm{MCH}(\mathrm{pg})=35.8$ (31.7-40), $\mathrm{MCHC}(\mathrm{g} / \mathrm{dl})=33$ (30.1- 35.2), RDW (\%)= 17.1 (14.1-20.3). We observed some differences in hematologic values of neotanal cord blood in comparison with other references which are in use in daily clinical practice. Especially RBCs and hemoglobin were higher and MCV, WBC and absolute neutrophil count were lower.
\end{abstract}

Keywords: Hematology, Neonate, Reference range, Hematologic reference values

\section{ÖZET}

İran-Mashhad'de Yenidoğanlarda Hematolojik Referans Değerlerinin Belirlenmesi

Farkı klinik durumlarda interval değerlerinin önemi gösterilmeden laboratuar test sonuçlarının pratik kullanımı mümkün değildir. Irk, çevre, örnek alım zamanı, test yöntemi, kanın örneğinin alındığı bölge, hamilelik yaşı ve anneye ait faktörler hematolojik değerleri etkilemektedir. Bu faktörler toplumlar arasında farkllık gösterdiğinden referans hematolojik değerler de farklı olmaktadır. Eylül 2007 ile mart 2008 tarihleri arasında 2500 gram üzerindeki 447 sağlıklı yenidoğanın kord kanı EDTA'lı tüplere alındı. Sysmex cell counter kullanılarak tam kan sayımı, hemoglobin, hematokrit ve eritrosit indeksleri ölçüldü. Periferik yayma yapılarak diferansiyel lökosit sayılarına bakıldı. Veriler SPSS programı (version 11.5) ile analiz edildi. Anlamılık düzeyi p <0.05 olarak alındı. Hematolojik parametrelerin ortanca ve aralık değerleri şu şekilde idi: WBC $\left(x 10^{3} \mu l\right)=11.62(5.16-18.2)$, RBC $\left(\mathrm{x} 10^{6} \mu \mathrm{l}\right)=4.45(3.61-5.29), \mathrm{Hb}(\mathrm{g} / \mathrm{dl})=15.9(13-18.8)$, Hct $(\%)=48.3$ (39.6-56.9), MCV $(\mathrm{fl})=108.7$ (97.5-119.8), MCH $(\mathrm{pg})=$ $35.8(31.7-40), \mathrm{MCHC}(\mathrm{g} / \mathrm{dl})=33$ (30.1-35.2), RDW (\%)= 17.1 (14.1-20.3). Yeni doğan kord kan örneklerindeki hematolojik değerlerin günlük klinik uygulamada kulanılan diğer referans değerlerden farklı olduğunu bulduk. Eritrosit ve hemoglobin daha yüksek iken, MCV, WBC ve absolü notrofil sayılarının daha düşük olduğu saptandı.

Anahtar Kelimeler: Hematoloji, Yenidoğan, Referans değer, Hematolojik referans değerler 


\section{INTRODUCTION}

The laboratory results have low clinical value unless clinical studies have ascribed various states of health and disease to the values of these tests and their intervals. ${ }^{1}$ We therefore need reference values for all laboratory tests performed in the clinical practice, not only from healthy individuals but from patients with relevant the most hematologic and non- hematologic diseases. In some diseases such as anemia these values are used for diagnosis to be considered as the basis for treatment. Hematologic values are affected by many different factors such as sex, gender, race, environment, time and place of sampling. ${ }^{2}$ Also in neonates, factors such as the gestational age, day of life, maternal factors, mode of delivery and site of blood collection can affect the results. ${ }^{3}$ Much information relevant to managing neonatal patients can be obtained from a complete blood count (CBC). ${ }^{4}$ Reference ranges for these parameters include values obtained on the day of birth based on gestational age, plus values obtained during the weeks following birth, based on postnatal age. ${ }^{5,6}$

Detecting abnormally high or low CBC elements can influence clinical decisions dramatically. Most of the time, we extract reference values from American or European population documents where as several factors mentioned above as well as characteristic of mother can influence these ranges. Therefore, in this study we have determined the reference values of hematological tests in neonates of Mashhad. The results will be a diagnostic and therapuetic base for our neonates in Mashhad.

\section{MATERIALS AND METHODS}

This study was performed for determination of Hematologic reference values in neonates in Mashhad, Iran, between September 9th 2007 and March 19th 2008. Subjects were selected randomly in several hospitals in the different regions of Mashhad and informed consent was obtained from the mothers.

We included 447 full term healthy newborns with healthy mothers in the study. A normal neonate was defined as one without maternal, intrapartum or neonatal complications who also had a normal physical examination at the time the sample was collected. Clinical information were collected for each neonate including birth weight, sex, gestational age, postnatal age, maternal complications (temperature $\geq 38^{\circ} \mathrm{C}$ within 24 hours of delivery, use of intrapartum antibiotics, diabetes mellitus, pregnancyinduced hypertension, chronic hypertension) intrapartum complications (length of membrane rapture, use of oxytocin, fetal bradycardia,...) and Apgar score. The mothers were considered healthy if they had not acute or chronic diseases, anemia, hypertension, diabetes mellitus and pregnancy complications such as eclampsia. Neonates with hyaline membrane disease, transient tachypnea, meconium aspiration syndrome, pneumonia thorax, bacterial diseases, hemolytic diseases and hyperbilirubinemia or non healthy mothers were excluded from the study. Immediately after birth, 2 cc blood was taken from umbilical cord and was mixed with ethylenediaminetetraacetic acid (EDTA- K2) anticoagulant. At the 4th hour of sampling, Complete blood count was performed by cell counter (Sysmex K-21, Japan). The following parameters were determined: hemoglobin $(\mathrm{Hb})$ levels, hematocrit $(\mathrm{HCT})$, red blood cells (RBCs) count, mean corpuscular volume (MCV), mean corpuscular hemoglobin ( $\mathrm{MCH})$, mean corpuscular hemoglobin concentration (MCHC) red cell distribution width (RDW), white blood cells (WBCs) count and platelet count. Before analyzing, instrument was calibrated with reference methods and after that daily quality control program were performed. Peripheral blood smears were prepared from all neonates and stained with Gimsa stain. At least, 200 WBCs were counted on a smear and differential leukocyte counts were determined. Normoblasts were not included in the differential but these cells were counted separately during the process. Then the WBC count for each sample was corrected by subtracting the absolute number of normoblasts. We also controlled platelet counts on smears to diagnose potential false increase or decrease in platelets.

Statistics: Data were statistically analyzed using the statistical package for social science (SPSS, version 11.5). For variables with normal distribution, mean $\pm 1.96 \mathrm{SD}$ was considered as the normal range which contains $95 \%$ of normal individuals. When distribution was not normal, reference ranges were considered values between 2.5 and 97.5 percentiles. Difference between mean of variables in our study compare with other studies were done by one sample t- test. A p value $<0.05$ was considered to be significant. 
Table 1. Reference values of RBCs results in our study compared with other two studies ${ }^{23,24}$

\begin{tabular}{|llll|}
\hline $\begin{array}{l}\text { Mean (95\% reference interval) } \\
\text { Study } 2^{23}\end{array}$ & $\begin{array}{l}\text { (95\% reference interval) } \\
\text { Study } 1^{24}\end{array}$ & $\begin{array}{l} \pm 1.96 \mathrm{SD}(95 \% \text { reference interval) } \\
\text { Our study }\end{array}$ & $\begin{array}{l}\text { Parameter } \\
\text { Reference values }\end{array}$ \\
\hline $4.3(3.5-5.1)$ & $4.5-5.8$ & $4.45(3.61-5.29)$ & RBCs (CE $\left.\times 10^{6} \mu \mathrm{l}\right)$ \\
$15.3(12.7-17.9)$ & $14-20$ & $15.9(13-18.8)$ & Hemoglobin $(\mathrm{g} / \mathrm{dll})$ \\
$49(38-59)$ & 43.63 & $48.3(39.6-56.9)$ & Hematocrit (\%) \\
$112(100-124)$ & $100-120$ & $108.7(97.5-119.8)$ & $\mathrm{MCV}(\mathrm{fl})$ \\
$36.2(31.8-40.6)$ & $32-40$ & $35.8(31.7-40)$ & $\mathrm{MCH}(\mathrm{pg})$ \\
$30.9(28.3-33.5)$ & $30-34$ & $33(30.1-35.2)$ & $\mathrm{MCHC}(\mathrm{g} / \mathrm{dl})$ \\
- & - & $17.1(14.1-20.3)$ & $\mathrm{RDW}(\%)$ \\
- & $200-600$ & $376(0-2298)$ & $\mathrm{NRBC}(\mu \mathrm{ll})$ \\
\hline
\end{tabular}

\section{RESULTS}

Reference values of RBCs, $\mathrm{Hb}, \mathrm{HCT}, \mathrm{MCV}, \mathrm{MCH}$ and $\mathrm{MCHC}$ compare with other studies are shown in Table 1 . HCT $>65 \%$ was not seen in any newborn. Mean corrected leukocyte count and diferential count in comparison with other studies are shown in Table 2. Neutrophil count was less then 4 $\mathrm{x} 10^{3} \mu \mathrm{l}$ in $32 \%$, less than $1.5 \times 10^{3} \mu \mathrm{l}$ in $1.3 \%$ and more than $4 \times 10^{3} \mu \mathrm{l}$ in $76 \%$ of subjects. Mean platelet count and its indices are shown in Table 3. Thrombocytopenia less than $150 \times 10^{3} \mu \mathrm{l}$ and less than $100 \times 10^{3} \mu \mathrm{l}$ were observed in $6.2 \%$ and $0.7 \%$, respectively.

\section{DISCUSSION}

References values have a great impact on interpretation of a test results since there is always a need for comparing the obtained results with these valu- es. Reference values usually include $95 \%$ of health population in their measures. ${ }^{5}$ It is advised not to use the incorrect term of "normal range" since the concepts of health and disease are discussed from the laboratory point of view and reference values are not always derived from "healthy" people. To be more exact, it is better to use terms such as reference values or reference ranges. . $^{2,7,9}$ It is recommended to include at least 120 samples for obtaining reference values in a population. ${ }^{2}$ To address this issue we considered more samples to increase the precision of reference values determination. Some studies have suggested that associated features such as gestational age, site of sampling (vein, capillary), kind of delivery, sex, environment and time and condition of sampling have influence on results. ${ }^{10-12}$ Despite this fact, some studies have shown that hematologic reference values in neonates do not relate to sex. ${ }^{13-14}$ Capillary blood vs. vein samp-

Table 2. Reference values of WBC $\left(\mu \mathrm{l} \times 10^{3}\right)$, absolute $\left(\mu \mathrm{l} \times 10^{3}\right)$ and relative leukocyte counts $(\%)$ in our study compared with other study ${ }^{23}$

\begin{tabular}{|c|c|c|c|c|c|c|c|c|c|c|c|c|c|c|c|}
\hline \multirow{3}{*}{$\begin{array}{l}\text { Our } \\
\text { study } \\
0.153\end{array}$} & \multicolumn{2}{|c|}{ Leukocyte } & \multicolumn{3}{|c|}{ Neutrophil } & \multicolumn{3}{|c|}{ Lymphocyte } & \multicolumn{3}{|c|}{ Monocyte } & \multicolumn{3}{|c|}{ Eosinophil } & Basophil \\
\hline & mean & range & mean & range & $\%$ & mean & range & $\%$ & mean & range & $\%$ & mean & range & $\%$ & mean range \\
\hline & 11.62 & $5.16-18.2$ & 5.68 & $1.12-10.2$ & 48 & 4.8 & $1.14-8.46$ & 42 & 0.738 & $0.9-1.64$ & 7 & 0.38 & $0.87-1.29$ & 3 & 0.0050 \\
\hline $\begin{array}{l}\text { Other } \\
\text { study* }\end{array}$ & 18 & $9-30$ & 10.98 & - & 61 & 5.58 & - & 31 & 1.08 & - & 6 & 0.36 & - & 2 & - \\
\hline
\end{tabular}


Table 3. Reference values of platelet in our study compared with other study ${ }^{11,23}$

\begin{tabular}{|lll|}
\hline Other study & Mean (reference interval) & Parameter / Value \\
\hline $288(182-394)^{23}$ & $257(131-383)$ & Platelet count $\left(\mu \mathrm{l} \times 10^{3}\right)$ \\
$8.9(8.5-11.3)^{11}$ & $9.9(8.5-11.6)$ & MPV (fl) \\
- & $12(9.4-16.4)$ & PDW (fl) \\
- & $24.2(13.4-35)$ & P-LCR $(\%){ }^{*}$ \\
\hline * Platelet large cells ratio & & \\
\hline
\end{tabular}

le has more $\mathrm{RBCs}$ and $\mathrm{Hb}$ levels. ${ }^{15}$ Also results of vein samples have more stability than capillary samples have and Cord blood hemoglobin is lower in the presence of low maternal hemoglobin. ${ }^{16}$ In our study we tried to standardize all the parameters that can affect results of our laboratory tests. As shown in Table 1; mean RBCs, Hb, and MCHC in comparison with study number 2 are higher and HCT, MCH, and MCV are lower. However, in studies performed in Ghazvin and Mashhad on adults, values of RBCs and $\mathrm{Hb}$ were higher and MCV was lower than European reference values. ${ }^{17,18}$ These differences could be related to race and geographic factors especially altitude from sea level (15). Lower MCV in our study may be related to high prevalence of iron deficiency anemia and iron depletion especially in women ${ }^{17,19}$ and higher incidence of thalassemia (3-4\%) in this region. ${ }^{10}$ Polycytemia (HCT $>65 \%$ ) in preterm and SGA neonates are relatively common, however in our study we did not find any polycythemia. It is probably because of selecting term and AGA neonates in this study. RDW shows difference in size of RBCs. Reference value in adults is less than $14 \%$ (18). Compare to this range, we had some higher value of reference rage for RDW (Table 1).

Normoblasts are seen normally in blood of neonates during the first week of life. ${ }^{9,11,15}$ In this research, absolute normoblast count in peripheral blood was more than the other studies. We can not explain this finding exactly; however, it may be related to fetal hypoxia (Table 1). Leukocyte count in the first day of birth is higher than the other days of life and is affected by many factors ${ }^{20}$ such as type of delivery. It has been shown that neonates delivered by cesarean section have lower level of leukocyte count than neonates with normal delivery. ${ }^{16}$ As shown in table 2, means absolute leukocyte count was lower in our study. These may be related to the type of delivery and race. Another study performed in Mashhad on adults confirms our finding on leukocyte count. Absolute Neutrophil count less than $4 \times 10^{3} \mu \mathrm{l}$ in the first day of life is defined as neutropenia. ${ }^{11}$ According to this definition, $23 \%$ of individuals in this study had neutropenia. This finding also underscores that each region should be its own reference values and base on this ranges, diagnosis and treatment should be done.

Platelet count in our study was lower than the result of study 1 (Table 3) where as in another study mean platelet count was higher. ${ }^{11}$ It is shown that platelet count is mildly lower than adult range in the first days of life but it reaches the adult level after 7 th day of labor. ${ }^{15}$ MPV has a reverse relation with palate count. PDW shows difference in platelet size. ${ }^{15,21}$ In a study performed in Mashhad on adults, reference range for MPV was reported 7.4 - 10.7 fl..$^{22}$ Power of the study was comparison of all parameters of $\mathrm{CBC}$ in the significant numbers of the neonates with the results of other studies. A limitation of study was determination of reference ranges only in venous blood; it was better we also determined them in the capillary blood.

As a conclusion, reference values in umbilical cord of term neonates in our study has some differences with other studies; especially, RBCs and hemoglobin were higher and MCV, WBC and absolute neutrophil count were lower. This point should be considered in interpreting the test results and applying them in diagnosis and treatment. 


\section{Acknowledgements}

This work was financially supported by the research vice chancellor, Mashhad University of Medical Sciences. We are thus grateful to him. We also thank Dr. Ismaili for the statistical advices.

\section{REFERENCES}

1. Roberts WL, McMillin GA, Burtis CA, Bruns DE. Reference information for the clinical laboratory. In: Burtis CA, Ashwood ER, Bruns DE, editors. Tietz textbook of clinical chemistry and molecular diagnostics. 4th ed ed. Elsevier Saunders, Philadelphia, 2006: 2251-2253.

2. Solberg HE. Establishment and use of reference. In: Burtis CA, Ashwood ER, Bruns DE, editors. Tietz textbook of clinical chemistry and molecular diagnostics. 4th ed. Elsevier Saunders, Philadelphia, 2006: 425-449.

3. Lokeshwar MR, Dalal R, Manglani M, Shah N. Anemia in newborn. Indian J Pediatr 65: 651-661, 1998.

4. Christensen RD, Henry E, Jopling J, Wiedmeier SE. The CBC: reference ranges for neonates. Seminars Perinatol 33: 3-11, 2009.

5. Jopling J, Henry E, Weidmeier SE. Reference ranges for hematocrit and blood hemoglobin concentration during the neonatal period: Data from a multihospital healthcare system. Pediatrics 123: e333-337, 2009.

6. Christensen RD, Jopling J. The erythrocyte indices of neonates, defined using data from over 12000 patients in a multihospital healthcare system. J Perinatal 28: 24-28, 2008.

7. Kanno T. Practical subjects of reference interval. Rinsho Byori 44: 241-244, 1998.

8. Grasbeck R. Reference values, why and how. Scand J Clin Lab Invest Suppl. 201: 45-53, 1990.

9. Lewis SM. Reference ranges and normal values. In: Lewis SM, Bain BJ, Bates I, editors. Dacie and Lewis practical haematology. 10th ed. Churchill Livingstone, Philadelphia, 2006: 9-15.

10. Keramati MR, Maybodi NT. The effect of Iron Deficiency Anemia (IDA) on the HbA2 level and comparison of hematologic values between IDA and thalassemia minor. UHOD 17: 151-156, 2007.

11. Ozyurek E, Cetintas S, Ceylan T, et al. Complete blood count parameters for healthy, small-for-gestationalage, full-term newborns. Clin Lab Haematol 28: $97-$ 104, 2006.

12. Kayiran SM, Ozbek N, Turan M, Gurakan B. Significant differences between capillary and venous complete blood counts in the neonatal period. Clin Lab Haematol 25: 9-16, 2003.

13. Mukiibi JM, Nkrumah FK, Kaur M, et al. Neonatal haematology in Zimbabwe. I: The platelet parameters. Cent Afr J Med 40: 80-83, 1994.

14. Mukiibi JM, Mtimavalye LA, Broadhead R, et al. Some haematological parameters in Malawian neonates. East Afr Med J 72: 10-14, 1995.
15. Vajpayee N, Graham SS, Bem S. Basic examination of blood and bone marrow. In: Mcpherson RA, Pincus MR, editors. Henry's Clinical diagnosis and management by laboratory methods. 21th ed. Saunders Elsevier, Philadelphia, 2007: 457-478.

16. Marwaha N, Marwaha RK, Narang A, et al. Routine hematological values in term newborns. Indian Pediatr 29: 1095-1099, 1992.

17. Shaikhol-Islami A, Kabiri H. Prevalence of iron deficiency anemia in women refered to health center in Ghazvin. Journal of Ghazvin University Medical Science 65: 55-67, 2008.

18. Tabarestani M, Keramati M, Maroozi F, Keramati A. Determination of hematologic reference value in different age and sex in Mashhad. Ofogh danesh 13: $27-$ 32, 2007.

19. Javadzadeh SH, Attar M, Taher Yavari M. A study of the prevalence of iron deficiency and its related factors in blood donors of Yazd, Iran, 2003. Transfus Med 15: 287-93, 2005.

20. Skubitz KM. Neutrophilic leukocyte. In: Greer J, Foerster J, Lukens J, Rodgers G, Paraskevas F, Glader B, editors. Wintrob's clinical hematology. 11th ed. Lipincott Williams and Wilkins, Philadelphia, 2004: 290292.

21. Tafazzoli M, Keramati MR, Vakili R. Etiology of thrombocytosis and the use of platelet parameters to distinguish between clonal and reactive thrombocytosis. UHOD 16: 71-76, 2006.

22. Adibi P, Emani F, Ghaneei M. Reference value of platelet indicators: Survey of 20000 cases. Journal of Esfehan Medical University Science 6: 106-108, 2001.

23. Brugnara C. Reference Values in infancy and childhood. In: Nathan DG, Orkin SH, Ginsburg D, Look AT, editors. Nathan and ski's hematology of infancy and childhood. Saunders Company, Philadelphia, 2003: 1838-1850.

24. Nock ML, Patra K. Tables of normal values. In: Marin RJ, Fanaroff AA, Walsh MC, editors. Fanaroff and Martin's neonatal perinatal medicine, diseases of the fetus and infant. 8th ed. Elsevier Mosby, Philadelphia, 2006: 1810-1814.

\section{Correspondence}

Ashraf MOHAMMADZADEH

Neonatal Research Center

School of Medicine

Mashhad University of Medical Sciences

Mashhad / IRAN

Tel: (+98.511) 8521121

Fax: (+98.511) 8525316

Email: Mohamadzadeha@mums.ac.ir 